\title{
Endotoxin Induces Differentiated Contractile Responses in Porcine Pulmonary Arteries and Veins
}

\author{
Björn P. Persson ${ }^{a}$ Piet J.M. Boels ${ }^{c}$ Cecilia Lövdahl ${ }^{b}$ Patrik Rossi $^{a}$ \\ Anders Arner $^{\mathrm{b}}$ Anders Oldner ${ }^{\mathrm{a}}$ \\ Sections of a Anaesthesiology and Intensive Care Medicine and ${ }^{b}$ Genetic Physiology, Department of Physiology \\ and Pharmacology, and ' Experimental Allergy and Asthma Research, Department of Environmental Medicine, \\ Karolinska Institutet, Stockholm, Sweden
}

\section{Key Words}

Pulmonary circulation $\cdot$ Endothelin-1 $\cdot$ Constriction . Relaxation - Western blot $\cdot$ Immunohistochemistry Acute lung injury

\begin{abstract}
Background/Aims: Sepsis-induced lung injury is characterized by pulmonary hypertension, edema and deteriorated gas exchange. As in vivo studies have indicated that bacterial endotoxin predominantly induces a pulmonary venous constriction, we aimed to investigate effects of endotoxin on isolated porcine pulmonary vessels. Methods: Pulmonary arteries and veins were examined using in vitro isometric force recordings. Endothelin-receptor protein expression and distribution were analyzed by Western blot and immunohistochemistry. Freshly isolated preparations and vessels incubated $(24 \mathrm{~h})$ with/without endotoxin $\left(10 \mu \mathrm{g} \cdot \mathrm{ml}^{-1}\right)$ were compared. The contractile responses to phenylephrine, UK14.304, U46619, PGF ${ }_{2 \alpha}$ endothelin-1 (ET-1) and sarafotoxin were recorded, as well as the relaxation in response to acetylcholine, isoproterenol and nitroprusside. Results: In freshly isolated vessels, phenylephrine-induced contractions had a 5-times larger amplitude in arteries than in veins. The amplitude of the contractions in response to sarafotoxin was
\end{abstract}

nearly 2 times larger in veins than in arteries, but there was no difference in responses to ET-1. Endotoxin markedly reduced phenylephrine-induced contractions in both arteries and veins, whereas the responses to ET-1 and sarafotoxin were augmented in veins only. No apparent changes in ET receptor expression or distribution were detected with Western blot or immunohistochemistry. Conclusion: Endotoxin differentially and selectively alters the contractile responses of porcine pulmonary vessels in vitro, towards a situation where the $\alpha-1$ adrenergic responses of arteries are attenuated and the ET responses of veins are augmented. In situations with high adrenergic activity and high circulating ET levels, such as sepsis, these results may provide a mechanism contributing to pulmonary hypertension and edema formation.

Copyright $\odot 2010$ S. Karger AG, Basel

\section{Introduction}

Acute lung injury (ALI), characterized by deteriorated gas exchange and pulmonary hypertension, is a frequent and severe complication of sepsis in man and is associated with considerable mortality [1]. This condition can be reproduced and examined in large animal experimen-

\section{KARGER}

Fax +4161306 1234 E-Mail karger@karger.ch www.karger.com
(C) 2010 S. Karger AG, Base

$1018-1172 / 11 / 0483-0206 \$ 38.00 / 0$

Accessible online at:

www.karger.com/jvr
Dr. Björn Persson

Department of Anaesthesiology and Intensive Care Medicine

Karolinska University Hospital, Solna

SE-171 76 Stockholm (Sweden)

Tel. +46 736220 512, Fax +46 830 7795, E-Mail bjorn.persson@karolinska.se 
tal models where intravenous endotoxin (lipopolysaccharide), isolated from the cell wall of Gram-negative bacteria, induces a powerful sepsis-like response as well as the manifestations of ALI [2-4]. The reaction to endotoxin includes major regional and systemic vasomotor disturbances, widely affecting both systemic and pulmonary circulations [5]. In the systemic circulation, the lowered resistance contributes to arterial hypotension and hypoperfusion of vital organs, leading to ischemia and organ failure. In the pulmonary circulation, endotoxininduced hypertension contributes to formation of pulmonary edema, deteriorated gas exchange and to potential strain on the right ventricle of the heart. The hydrostatic pressure in the pulmonary capillaries is a crucial determinant of edema formation and, depending on the site where the constrictor effect dominates, pulmonary vascular constrictors may affect this pressure differentially. Thus, given an identical overall increase in pulmonary resistance, a constrictor with a predominantly venous site of action will generate a relatively higher capillary pressure with potential subsequent edema formation as compared with a constrictor with arterial predominance. Endotoxin has been shown to induce pulmonary hypertension largely characterized by increased venous resistance [6], potentially causing edema, impaired gas exchange and reduced pulmonary compliance, all hallmarks of ALI.

The endogenous, pro-inflammatory and highly vasoconstrictive peptide endothelin-1 (ET-1) is largely produced and released by the endothelium [7]. The levels of ET-1 are elevated in patients with sepsis [8] and ALI and correlate with the severity of illness [9-11]. We and others have shown that ET-1 is also involved in the formation of extravascular lung water and development of pulmonary hypertension during experimental endotoxemia. Furthermore, these detrimental pulmonary effects are counteracted by ET-receptor antagonism $[3,12,13]$. The mechanisms involved in the ET-1-mediated effects on edema formation during endotoxemia are not yet resolved. Possibly they include effects of ET-1 on pulmonary capillary pressure, capillary permeability and alveolar fluid clearance. Previous studies from our laboratory have shown that ET-receptor stimulation predominantly induces a venous constriction in the porcine pulmonary circulation, both in vivo and in isolated pulmonary vessels. Thus, ET-1 may play an important role in endotoxin-induced lung injury.

In the vasculature, ET-1 mediates its effects via two receptor subtypes: endothelin type $\mathrm{A}\left(\mathrm{ET}_{\mathrm{A}}\right)$ and endothelin type $\mathrm{B}\left(\mathrm{ET}_{\mathrm{B}}\right)$ receptors. The $\mathrm{ET}_{\mathrm{A}}$ receptors are mainly located on the vascular smooth muscle cells and mediate not only vasoconstriction but also smooth muscle cells proliferation [14]. The $\mathrm{ET}_{\mathrm{B}}$ receptors are localized both on the vascular smooth muscle cells and on the endothelial cells, mediating contraction in the former and relaxation in the latter through release of nitric oxide (NO) and prostacyclin. In addition, the endothelial $\mathrm{ET}_{\mathrm{B}}$ receptors clear ET-1 from the circulation via endocytosis of the receptor-ligand complex [14]. As the $\mathrm{ET}_{\mathrm{A}}$ and $\mathrm{ET}_{\mathrm{B}}$ receptors in part have different effects on vascular tone, changes in receptor distribution and density can have an impact on vascular resistances and pressures.

Endotoxin has been shown to induce major vasomotor disturbances involving effects on responses to both vasoconstrictive and vasodilating substances in various animal models and vascular beds [15-19]. Many of these substances in the vascular wall are also highly involved in the pathophysiology of sepsis, but their integrated action in the pulmonary vasculature during endotoxaemia, and ALI, is not fully elucidated. In particular, an analysis of differentiated effects on pulmonary arterial and venous resistance would be of importance for understanding of the mechanisms involved in edema formation. Although the in vivo experiments on animal models are of key clinical relevance, a more mechanistic analysis of the effects of endotoxin on specific vessels and on vascular signaling requires an approach where the effects on vessel segments can be isolated. To address this issue, we have developed an in vitro organ culture/incubation model for porcine pulmonary arteries and veins and examined the direct effects of endotoxin on contractile function and vascular reactivity. The vessel preparations were examined using in vitro experiments after $24 \mathrm{~h}$ incubation with or without endotoxin. In addition, Western blot and immunohistochemistry was performed to investigate endotoxin-induced changes of ET receptor expression and distribution.

Parts of this study were presented in a preliminary form at the 10th conference of the World Federation of Societies of Intensive and Critical Care Medicine, Florence, Italy in 2009.

\section{Material and Methods}

Vascular Preparations

Freshly harvested lungs from domestic landrace pigs of both sexes, 60-90 days of age, were obtained at the regional abattoir. The basal third of the lower lobe was cut and rinsed with a cold transport buffer solution (content see below). The lung tissue was stored in the buffer solution and transported on ice to the laboratory within $1 \mathrm{~h}$. Pulmonary arteries and veins were identified and 
carefully dissected under sterile conditions. Three rings (internal circumference $8.9-15.2 \mathrm{~mm}$ corresponding to 2 nd to $3 \mathrm{rd}$ branching, segment length 1.1-4.3 $\mathrm{mm}$ ) were cut from each type of vessel. After dissection, two rings from each vessel type were incubated, one with endotoxin and one without, while the third vessel was used for immediate experimentation.

\section{Vessel Incubation}

After dissection, the vessel rings were placed in $5 \mathrm{ml}$ sterile Dulbecco's Modified Eagle's Medium (DMEM) supplemented with penicillin $100 \mathrm{U} \cdot \mathrm{ml}^{-1}$, streptomycin $100 \mu \mathrm{g} \cdot \mathrm{ml}^{-1}$ and L-glutamine $2 \mathrm{mM}$. One vessel of each type was exposed to endotoxin (Escherichia coli, serotype O127:B8) at a concentration of 10 $\mu \mathrm{g} \cdot \mathrm{ml}^{-1}$ during the incubation, whereas the corresponding control vessels were kept in endotoxin-free medium. The vessels were then kept for $24 \mathrm{~h}$ at $37^{\circ} \mathrm{C}$ in a humidified atmosphere with $5 \%$ $\mathrm{CO}_{2}$ in air.

\section{Experimental Protocol}

In vitro Pharmacology

The arterial and venous vessel rings were mounted on two parallel stainless steel pins (diameter $0.2 \mathrm{~mm}$ ) in 6-ml organ baths of a 610M myograph system (DMT Danish Myo Technology A/S, Aarhus, Denmark) filled with Krebs-Ringer physiological salt solution (PSS) continuously gassed with $95 \% \mathrm{O}_{2} / 5 \% \mathrm{CO}_{2}$ at a temperature of $37^{\circ} \mathrm{C}$. One pin was connected to a force transducer and the other to a micrometer screw for length adjustment. Force data were collected with a computerized A/D converter (ADinstruments Ltd., Chalgrove, UK).

The vessels were stretched to the optimal circumference for maximal isometric force development [high $\mathrm{K}^{+}(125 \mathrm{mM})$-induced contraction is maximal]. This length was defined as the length (that is, circumference) at which the high potassium-induced contraction was maximal. In previous studies [20,21], this length was found to correlate with the initial slack circumference allowing an estimate of optimal length based on the slack circumference of the vessels. After stretching and equilibration for 60 min, the viability of the preparations was tested by measuring the contractile response to high $\mathrm{K}^{+}$. Preparations not contracting to $\mathrm{K}^{+}$were excluded from the study. This initial procedure was used for all preparations studied. After the baseline had returned to pre- $\mathrm{K}^{+}$-challenge levels, all preparations were challenged with 10 nM U46619 (stable thromboxane $\mathrm{A}_{2}$ analogue). After the contraction to this agonist had stabilized (approx. $5 \mathrm{~min}$ ), bradykinin $(1 \mu \mathrm{M}$, arteries) or acetylcholine (ACH; $10 \mu \mathrm{M}$, veins) were added. Failure to relax to these two agonists (in the freshly isolated vessels) excluded the preparations from further experimentation.

The responses to $\alpha$-receptor agonists were recorded by adding $10 \mu \mathrm{M}$ phenylephrine (PHE; $\alpha-1$ receptor agonist) or $10 \mu \mathrm{M}$ UK14.304 (brimonidine, $\alpha-2$ agonist). The effects of the $\beta$-receptor agonist isoproterenol (ISO) were assessed by adding the drug to a final concentration of $10 \mu \mathrm{M}$ in vessels preconstricted with 10 $\mathrm{nM}$ U46619. The relaxation to $\mathrm{ACH}$ was measured in rings precontracted using 10-30 $\mu \mathrm{M}$ U46619 to a steady-state force of at least $50 \%$ of that induced by high $\mathrm{K}^{+}$. To measure responses to ET-1 (ET $\mathrm{A}_{\mathrm{A}}$ and $\mathrm{ET}_{\mathrm{B}}$ receptor agonist) or sarafotoxin $6 \mathrm{c}$ (S6c; selective $\mathrm{ET}_{\mathrm{B}}$ receptor agonist), the peptides were added cumulatively (0.01-100 nM, log unit steps) and concentration-response relationships were recorded. These recordings ended the experiment as the effects of the peptides could not be washed away.
To assess endothelium-independent vasorelaxation, a separate set of precontracted incubated venous rings was exposed to $\mathrm{cu}-$ mulative concentrations ( $1 \mathrm{nM}$ to $1 \mathrm{mM}, \log$ unit steps) of sodium nitroprusside (SNP; NO donor) and concentration-response relationships were recorded. The segment lengths of the preparations were recorded at the end of the experiments.

Solutions and Chemicals

Serum-free DMEM was purchased from Invitrogen (Paisley, UK). ET-1 and S6c were purchased from American Peptide Inc. (Sunnyvale, Calif., USA). The other drugs used, including endotoxin, were obtained from Sigma-Aldrich (St. Louis, Mo., USA). All drugs were dissolved according to the instructions of the manufacturer and stored in aliquots at $-80^{\circ} \mathrm{C}$ until use. The transport buffer solution was composed of (in mM): $\mathrm{NaCl} \mathrm{145,} \mathrm{KCl} \mathrm{5,} \mathrm{CaCl}_{2}$ $2, \mathrm{MgSO}_{4} 1, \mathrm{NaH}_{2} \mathrm{PO}_{4} 1$, EDTA 0.02, MOPS 3, pyruvate 2, glucose 5 and titrated to $\mathrm{pH} 7.4$ with $\mathrm{NaOH}$. The Krebs-Ringer PSS solution contained (in mM): $\mathrm{NaCl} 118.5, \mathrm{KCl} 4.7, \mathrm{KH}_{2} \mathrm{PO}_{4} 1.2, \mathrm{MgCl}_{2}$ 1.2, $\mathrm{CaCl}_{2}$ 2.5, EDTA 0.026, glucose 11.1 and $\mathrm{NaHCO}_{3} 25$. The high- $\mathrm{K}^{+}$PSS was made by replacing $\mathrm{NaCl}$ with $\mathrm{KCl}$ in the solution. The PSS solutions were gassed with $95 \% \mathrm{O}_{2} / 5 \% \mathrm{CO}_{2}$.

Immunohistochemistry

Approximately $10-\mathrm{mm}$-long intact pieces of pulmonary artery and vein (freshly isolated, incubated $24 \mathrm{~h}$ with or without endotoxin $10 \mu \mathrm{g} \cdot \mathrm{ml}^{-1}$ ) were transferred to $4 \%$ paraformaldehyde for fixation for $24 \mathrm{~h}$, followed by $30 \%$ sucrose $(24 \mathrm{~h})$, washed in phosphate-buffered saline (PBS; $1 \mathrm{~h}$ ) and embedded for cryosectioning (8- $\mu \mathrm{m}$ sections). Sections were rehydrated and permeabilized in PBS $+0.1 \%$ Triton X-100 and unspecific binding was blocked with $5.5 \%$ horse serum $(1 \mathrm{~h})$, followed by primary antibody incubation overnight at $4{ }^{\circ} \mathrm{C}$. Antibodies for the $\mathrm{ET}_{\mathrm{A}}$ or $\mathrm{ET}_{\mathrm{B}}$ receptors (sc21193 and sc-21196, respectively; Santa Cruz Biotechnology, Santa Cruz, Calif., USA) and Cy3-conjugated SM- $\alpha$-actin (Sigma-Aldrich) were diluted 1:100. After washing, the sections were incubated with fluorescent secondary antibodies (Alexa Fluor 555 donkey-anti goat to detect $\mathrm{ET}_{\mathrm{A}^{-}}$and $\mathrm{ET}_{\mathrm{B}}$-receptors; Molecular Probes, Carlsbad, Calif., USA). After washing, the sections were finally incubated 2 min with $20 \mu \mathrm{M}$ nuclear stain DRAQ5 (Biostatus Ltd., Shepshed, UK), rinsed briefly and mounted with fluorescent mounting medium (Dako, Carpinteria, Calif., USA). The mounted sections were refrigerated dark until confocal microscopy analysis using a Zeiss META LSM 510 microscope (Carl Zeiss GmbH, Jena, Germany).

\section{Western Blots}

Samples from pulmonary vessels were extracted in a $50 \mathrm{mM}$ Tris, $\mathrm{pH} 7.5,1 \%$ Triton $\mathrm{X}-100,0.1 \%$ mercaptoethanol, $1 \%$ protease inhibitor cocktail (all reagents from Sigma-Aldrich), using a glass mortar and pestle for homogenization. Extracts were left on ice for $30 \mathrm{~min}$, further homogenized until completely dissolved, centrifuged at $12,000 \mathrm{~g}$ for $10 \mathrm{~min}$ and supernatant collected for protein determination in a NanoDrop (Thermo Scientific, Rockford, Ill., USA).

\section{Immunoblotting}

Seventy-five micrograms protein of tissue extracts was mixed with $5 \times$ SDS-Laemmli buffer and denatured at $100^{\circ} \mathrm{C}$ for $5 \mathrm{~min}$, separated by $4-12 \%$ polyacrylamide gel electrophoresis, and transferred to nitrocellulose membranes (Hybond ECL; Amers- 
Table 1. Inner circumference, active force responses and ET receptor protein levels (Western blot) of freshly isolated pulmonary arteries and veins, and of vessels incubated in organ culture for $24 \mathrm{~h}$ without and with $10 \mu \mathrm{g} \cdot \mathrm{ml}^{-1}$ endotoxin

\begin{tabular}{|c|c|c|c|c|c|c|}
\hline & \multirow{2}{*}{$\begin{array}{l}\text { Artery } \\
\text { (freshly } \\
\text { isolated) }\end{array}$} & \multirow{2}{*}{$\begin{array}{l}\text { Vein } \\
\text { (freshly } \\
\text { isolated) }\end{array}$} & \multicolumn{2}{|l|}{ Artery } & \multicolumn{2}{|l|}{ Vein } \\
\hline & & & incubated & + endotoxin & incubated & + endotoxin \\
\hline Number of vessels & 10 & 9 & 9 & 15 & 10 & 15 \\
\hline Circumference, $\mathrm{mm}$ & $11.6 \pm 1.0$ & $9.5 \pm 0.7$ & $8.5 \pm 0.8$ & $9.0 \pm 1.1$ & $8.5 \pm 0.7$ & $9.6 \pm 1.1$ \\
\hline Max. high $\mathrm{K}^{+}$tension, $\mathrm{mN} \mathrm{mm}^{-1}$ & $22.2 \pm 1.8$ & $24.7 \pm 2.2$ & $22.2 \pm 2.5$ & $16.9 \pm 1.7$ & $29.4 \pm 3.8$ & $19 \pm 2^{*}$ \\
\hline \multicolumn{7}{|l|}{ ET-1 responses } \\
\hline $\mathrm{EC}_{50}, \log \mathrm{M}$ & $-8.6 \pm 0.3$ & $-8.6 \pm 0.3$ & $-8.2 \pm 0.1$ & $-8.1 \pm 0.1$ & $-8.3 \pm 0.1$ & $-8.3 \pm 0.1$ \\
\hline Emax, \% & $129 \pm 7$ & $138 \pm 6$ & $134 \pm 9$ & $149 \pm 7$ & $126 \pm 7$ & $182 \pm 24$ \\
\hline \multicolumn{7}{|l|}{ S6c responses } \\
\hline $\mathrm{EC}_{50}, \log \mathrm{M}$ & $-8.6 \pm 0.3$ & $-8.6 \pm 0.3$ & $-8.2 \pm 0.1$ & $-8.1 \pm 0.1$ & $-8.3 \pm 0.1$ & $-8.3 \pm 0.1$ \\
\hline Emax, \% & $74 \pm 20$ & $116 \pm 13$ & $130 \pm 16$ & $130 \pm 17$ & $124 \pm 7$ & $153 \pm 6^{* *}$ \\
\hline $\mathrm{ET}_{\mathrm{A}}$ receptor protein levels, $\%$ of fresh & 100 & 100 & $99 \pm 1$ & $107 \pm 3$ & $106 \pm 14$ & $90 \pm 8$ \\
\hline $\mathrm{ET}_{\mathrm{B}}$ receptor protein levels, \% of fresh & 100 & 100 & $92 \pm 4$ & $88 \pm 3$ & $110 \pm 12$ & $101 \pm 10$ \\
\hline
\end{tabular}

The active tension in response to depolarizing high $\mathrm{K}^{+}$solution is related to segment length and given as wall tension. The maximal responses to ET-1 and sarafotoxin $6 \mathrm{c}$ are given in percentage of the high $\mathrm{K}^{+}$responses. The Emax and $\mathrm{EC}_{50}$ values were obtained by fitting a sigmoidal function to the force-concentration data. ET receptor protein levels are expressed as percentage of values for freshly isolated vessels ( $\mathrm{n}=4$ in each group).

${ }^{*} \mathrm{p}<0.05 ;{ }^{* *} \mathrm{p}<0.01$ for difference between incubated veins with and without endotoxin analyzed by Student's t test. ham Biosciences, Piscataway, N.J., USA). Ponceau staining was used to evaluate protein loading. Nonspecific binding sites were blocked by incubation in 3\% BSA. Membranes were incubated with specific antibodies (goat polyclonal) anti-ET $\mathrm{A}_{\mathrm{A}}$ and $\mathrm{ET}_{\mathrm{B}}$ receptor (sc-21193 and sc-21196, respectively; Santa Cruz), or mouse monoclonal antibody specific for smooth muscle-specific $\alpha$-actin (Sigma-Aldrich) diluted 1:1,000 at $+4^{\circ} \mathrm{C}$ overnight. After primary antibody incubation, membranes were washed 3 times $10 \mathrm{~min}$ in PBS containing $0.1 \%$ Tween. Bands were visualized after $1 \mathrm{~h}$ incubation with an HRP-conjugated secondary antibody (1:1,000 donkey-anti goat for $\mathrm{ET}_{\mathrm{A}}$ and $\mathrm{ET}_{\mathrm{B}}$ receptors; Santa Cruz; goatanti mouse 1:10,000 for SM $\alpha$-actin; Pierce Biotech Inc.) using ECL technique (Pierce Biotech Inc.) according to the manufacturer's instructions. Equal amount of protein of the different samples were loaded on each gel and the band ECL intensities (using GelDoc and image software; Bio-Rad, Sundbyberg, Sweden) were expressed as percentage of the intensities of bands from freshly isolated vessels.

\section{Data Analysis and Statistics}

Data are expressed as means \pm SEM. Numbers indicate the number of vessels obtained from different animals. Relaxation was calculated as percent of reduction of the active force at the stable plateau level.

Contractile responses to high $\mathrm{K}^{+}(125 \mathrm{mM})$ are expressed as the ratio of force and segment length (active tension, $\mathrm{mN} / \mathrm{mm}$ ) and the other responses are expressed as percentage of the maximal contraction induced by high $\mathrm{K}^{+}$. The force $(\mathrm{Y})$ and concentration (X) data were analyzed by fitting a sigmoidal function using nonlinear regression (implemented in Prism 4.0; GraphPad Software Inc., La Jolla, Calif., USA) using the formula: $\mathrm{Y}=\mathrm{E} \max \cdot \mathrm{X}^{h} /\left(\mathrm{X}^{h}+\right.$ $\mathrm{EC}_{50}{ }^{h}$ ), where Emax denotes the estimated maximal amplitude of the response, $h$ the steepness of the relationship (Hill coefficient) and $\mathrm{EC}_{50}$ the concentration giving half maximal response.

Differences in contractions and relaxations between the in vitro preparations and between band intensities from Western blot were analyzed using Student's t test. Concentration-response data were assessed using repeated measures analysis of variance (ANOVA). The statistical calculations were made using Statistica (version 7.0; StatSoft Inc., Tulsa, Okla., USA). A p value of less than 0.05 was considered statistically significant.

\section{Results}

\section{Vascular Reactivity of Freshly Isolated, Nonincubated,} Vessels

The active wall tension (force per segment length) in response to depolarization with high $\mathrm{K}^{+}$solution was similar in the freshly isolated nonincubated arteries and veins (table 1). In contrast, the $\alpha-1$ adrenergic agonist PHE induced a contraction that was more than 5-fold stronger in arteries than in veins (fig. 1a). No significant difference between arteries and veins was noted in response to the $\alpha-2$ adrenergic agonist UK14.304, which caused only small contractions in both preparations (fig. 1a). The response to the thromboxane $A_{2}$ analogue $\mathrm{U} 46619$ or to $\mathrm{PGF}_{2 \alpha}$ did not differ between freshly isolated arteries and veins (fig. 1a). The $\mathrm{ET}_{\mathrm{B}}$ receptor agonist S6c induced a nearly 2 -fold stronger contraction and was 


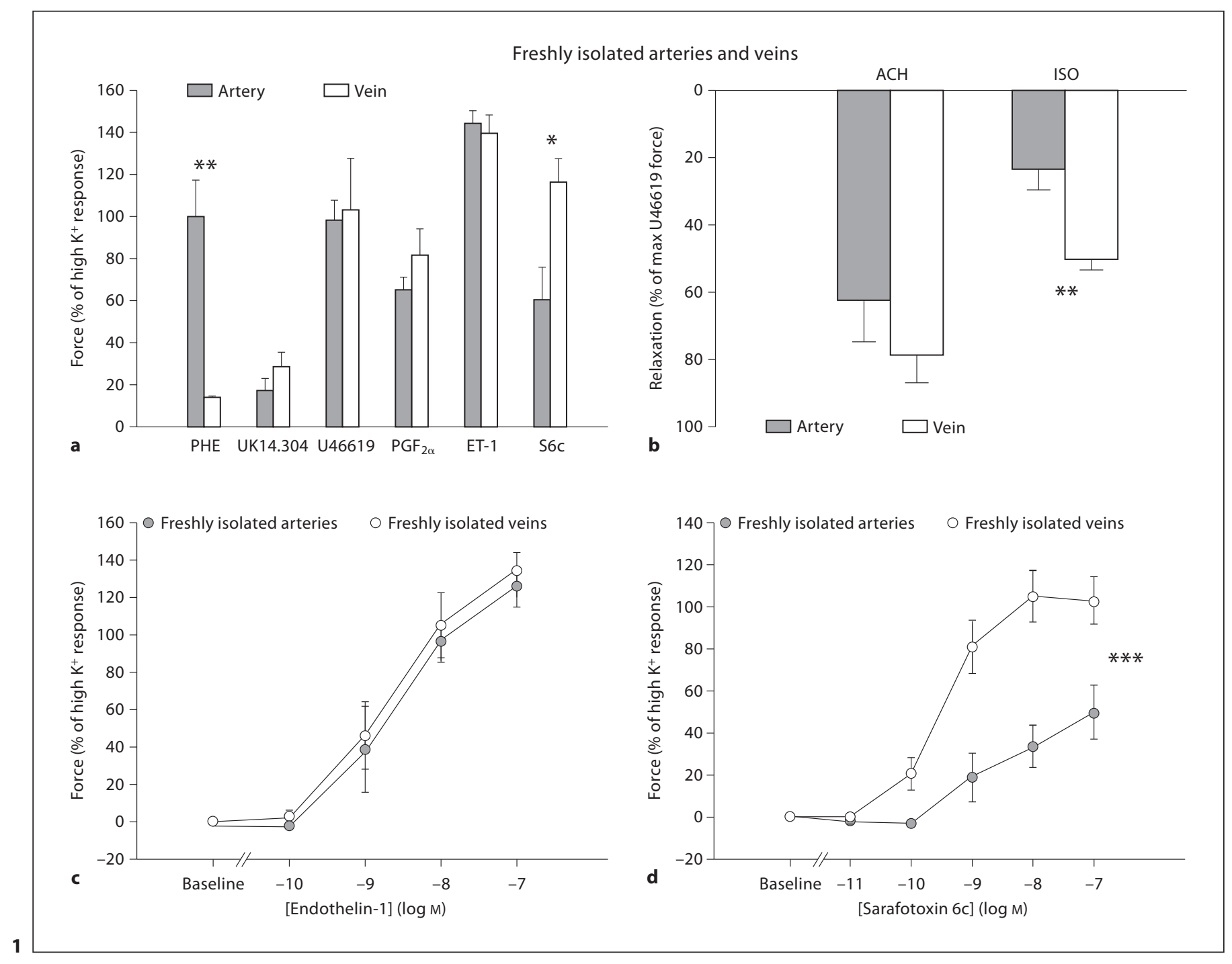

Fig. 1. a Effect of PHE (10 $\mu M, \alpha-1$ agonist, $\mathrm{n}=3$ and 3), UK14.304 (10 $\mu \mathrm{M}, \alpha$-2 agonist, $\mathrm{n}=6$ and 6), U46619 (10 nM, TxA2-analogue, $\mathrm{n}=5$ and 5), $\mathrm{PGF}_{2 \alpha}(1 \mu \mathrm{M}, \mathrm{n}=3$ and 3$), \mathrm{ET}-1$ (100 $\mathrm{nM}, \mathrm{n}=3$ and 3) and sarafotoxin $6 \mathrm{c}(100 \mathrm{nM}, \mathrm{S} 6 \mathrm{c}, \mathrm{n}=6$ and 6$)$ on freshly isolated rings of porcine pulmonary artery and vein. ${ }^{*} \mathrm{p}<0.05$; ${ }^{* *} \mathrm{p}<0.01$ for artery versus vein, analyzed by unpaired Student's t test. b Relaxing effects of ACH $(10 \mu \mathrm{M}, \mathrm{n}=6$ and 6$)$ and ISO (10 $\mu \mathrm{M}, \beta$-agonist, $\mathrm{n}=5$ and 5 ) on freshly isolated rings of porcine pulmonary artery and vein preconstricted with $10 \mathrm{nM}$ U46619. ${ }^{* *} p<0.01$ artery versus vein analyzed by unpaired Student's t test. c, d Concentration-response relationships for ET-1 ( $\mathrm{n}=3$ and 3$)$ and $56 \mathrm{c}(\mathrm{n}=6$ and 6$)$ in freshly isolated rings of porcine pulmonary artery and vein. Force values are given relative to the responses to high $\mathrm{K}^{+}$. ${ }^{* *} \mathrm{p}<0.001$ analyzed by repeated measures ANOVA. Values are presented as means \pm SEM.

Fig. 2. a Effect of PHE (10 $\mu \mathrm{M}, \alpha-1$ agonist, $\mathrm{n}=3$ and 3$), \mathrm{UK} 14.304$ (10 $\mu \mathrm{M}, \alpha$-2 agonist, $\mathrm{n}=6$ and 6), U46619 (10 nM, TxA2-analogue

$\mathrm{n}=5$ and 5), $\mathrm{PGF}_{2 \alpha}(1 \mu \mathrm{M}, \mathrm{n}=3$ and 3$), \mathrm{ET}-1(100 \mathrm{nM}, \mathrm{n}=3$ and 3) and $S 6 \mathrm{c}(100 \mathrm{nM}, \mathrm{n}=6$ and 6$)$ on pulmonary arteries incubated with or without endotoxin $10 \mu \mathrm{g} \cdot \mathrm{ml}^{-1}$ during $24 \mathrm{~h} .{ }^{*} \mathrm{p}<0.05$ without versus with endotoxin analyzed by unpaired Student's t test. b Effect of PHE (10 $\mu \mathrm{M}, \alpha-1$ agonist, $\mathrm{n}=3$ and 3), UK14.304 (10 $\mu \mathrm{M}, \alpha-2$ agonist, $\mathrm{n}=6$ and 6$), \mathrm{U} 46619$ (10 nM, TxA2-analogue $\mathrm{n}=5$ and 5), $\mathrm{PGF}_{2 \alpha}(1 \mu \mathrm{M}, \mathrm{n}=3$ and 3$), \mathrm{ET}-1$ (100 nM, $\mathrm{n}=3$ and 3) and $S 6 c(100 \mathrm{nM}, \mathrm{n}=6$ and 6$)$ on pulmonary veins incubated with or without endotoxin $10 \mu \mathrm{g} / \mathrm{ml}$ during $24 \mathrm{~h} .{ }^{*} \mathrm{p}<0.05$; ${ }^{* *} \mathrm{p}<0.01$ analyzed by unpaired Student's t test. c, $\mathbf{d}$ Concentration-response relationships for ET-1 on pulmonary artery and vein preparations incubated with or without endotoxin $10 \mu \mathrm{g} \cdot \mathrm{ml}^{-1}$ during $24 \mathrm{~h}(\mathrm{n}=3$ and 3$){ }^{*} \mathrm{p}<0.05$ analyzed by repeated measures ANOVA. e, f Concentration-response relationships for S6c on pulmonary artery and vein preparations incubated with or without endotoxin $10 \mu \mathrm{g} \cdot \mathrm{ml}^{-1}$ during $24 \mathrm{~h}(\mathrm{n}=6$ and 6$) .{ }^{*} \mathrm{p}<0.05$ analyzed by repeated measures ANOVA. 
Incubated artery

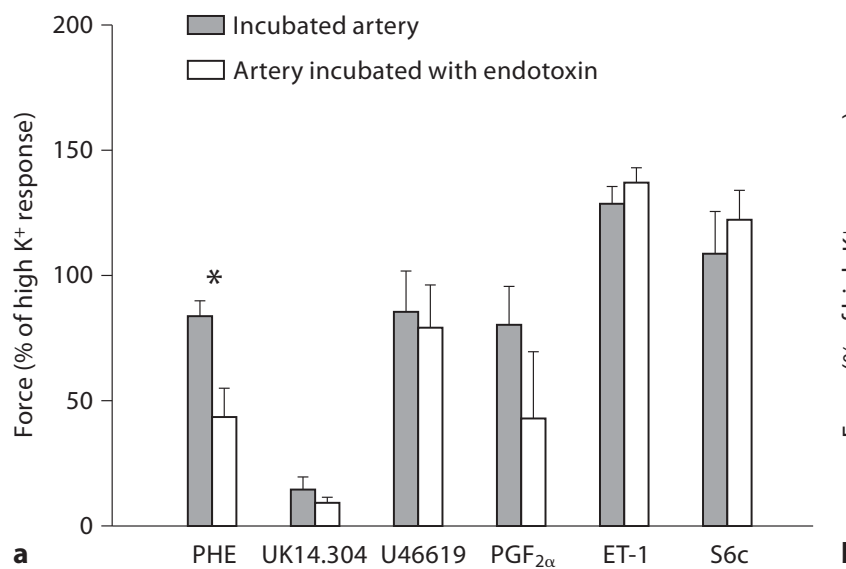

Incubated vein
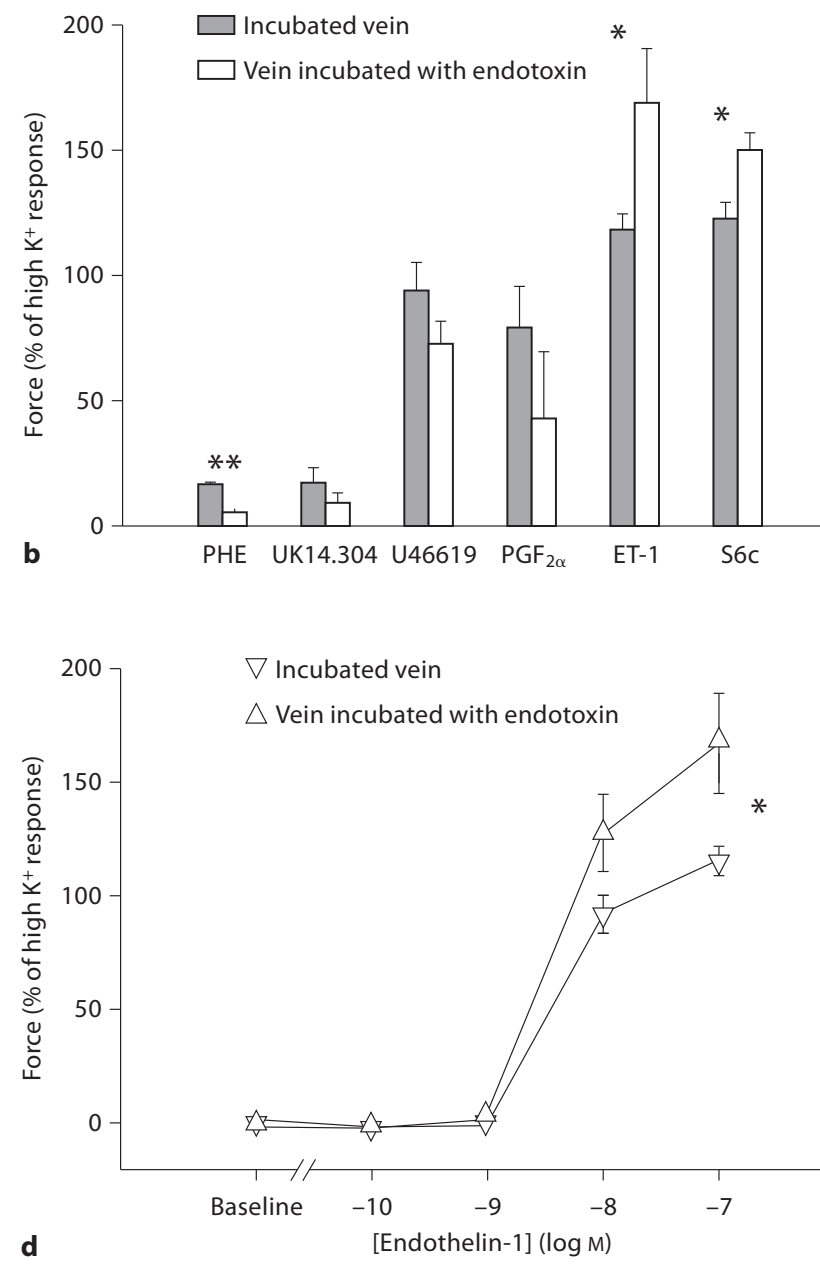

c
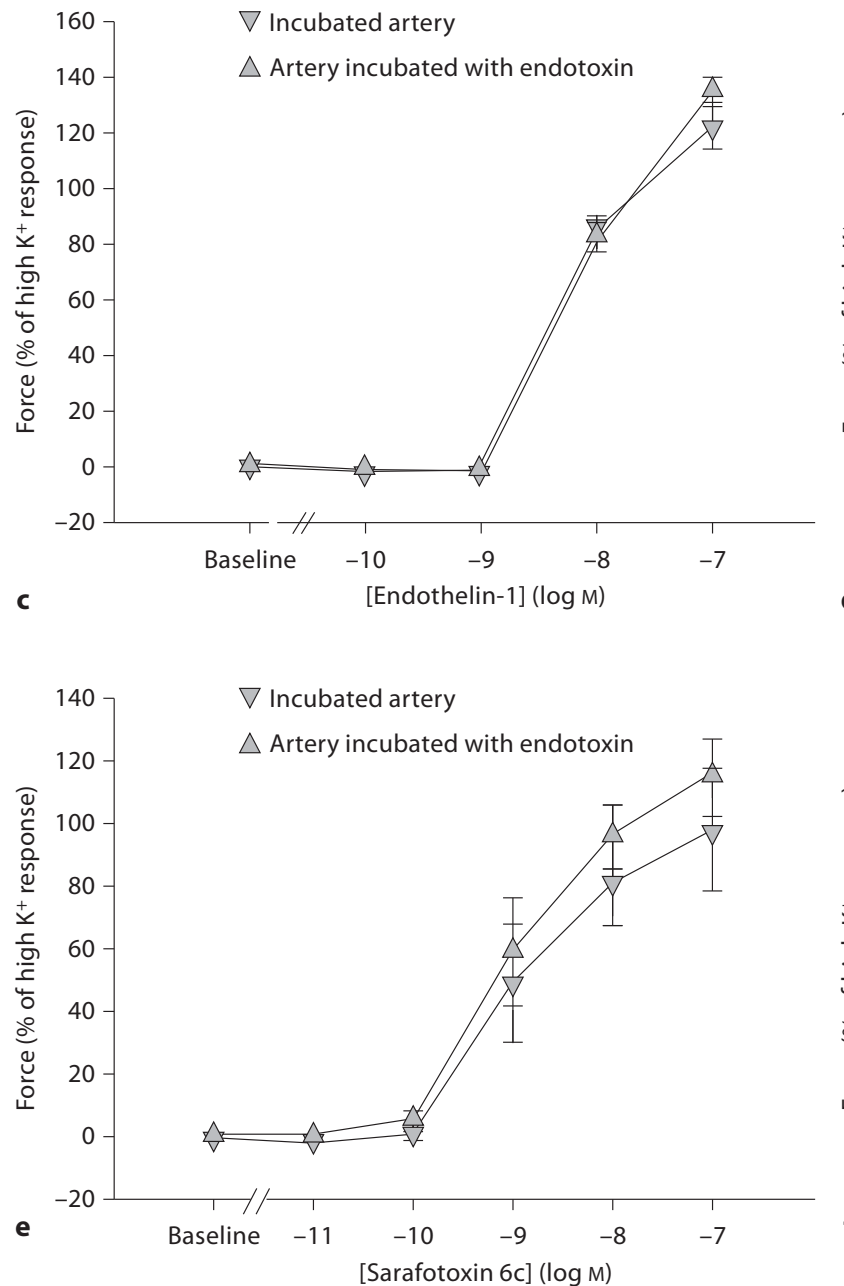

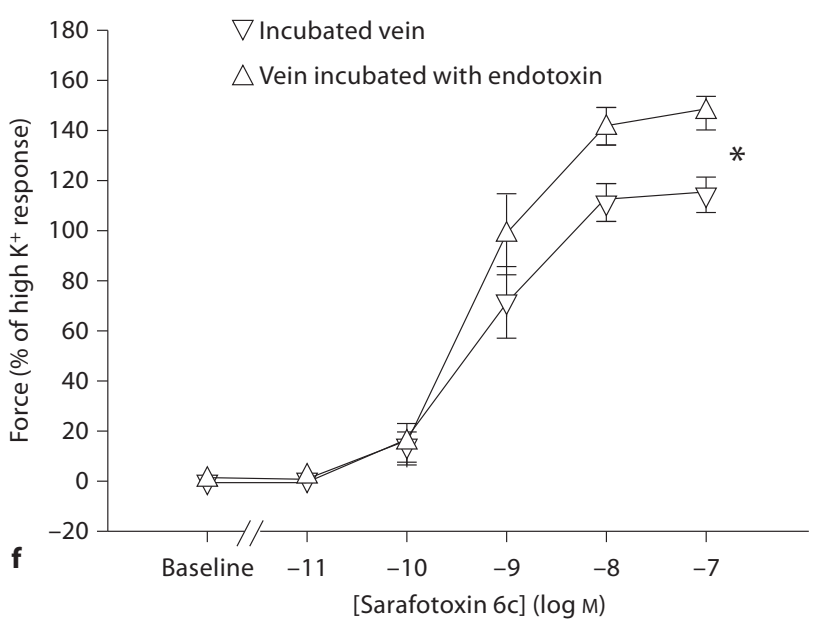




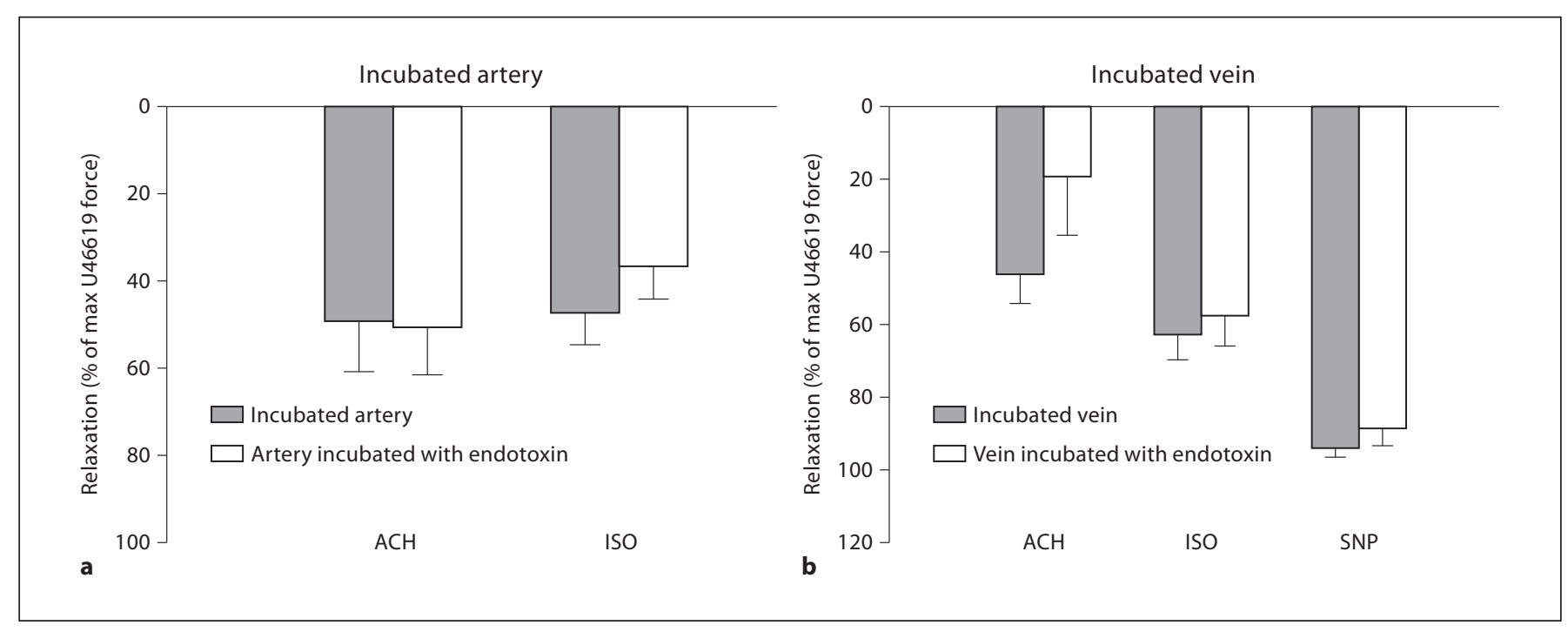

Fig. 3. a Effect of $\mathrm{ACH}(10 \mu \mathrm{M}, \mathrm{n}=6$ and 6$)$ and ISO $(10 \mu \mathrm{M}, \beta$-agonist, $\mathrm{n}=5$ and 5$)$ on incubated and endotoxin-incubated pulmonary arteries preconstricted with $10 \mathrm{nM}$ U46619. b Effect of ACH $(10 \mu \mathrm{M}, \mathrm{n}=5$ and 6), ISO (10 $\mu \mathrm{M}, \beta$-agonist, $\mathrm{n}=5$ and 5 ) and SNP (NO donor, $\mathrm{n}=8$ and 8 ) on incubated and endotoxin-incubated pulmonary veins preconstricted with $10 \mathrm{nM}$ U46619. Values are means \pm SEM.

active at lower concentrations in veins than in arteries (fig. 1a, d; table 1), whereas the response to the $\mathrm{ET}_{\mathrm{A}}$ and $\mathrm{ET}_{\mathrm{B}}$ receptor agonist ET-1 was equal (fig. 1a, c; table 1). In vessels preconstricted with U46619, the $\beta$-adrenergic agonist ISO induced a greater relaxation in veins compared to arteries. The responses to $\mathrm{ACH}$ were similar in the freshly isolated arteries and veins (fig. 1b).

\section{Effects of Incubation on Vascular Reactivity}

Incubation during $24 \mathrm{~h}$ induced only modest changes in active force generation of the vessels in response to membrane depolarization; the contraction induced by high $\mathrm{K}^{+}$(table 1) was not significantly altered compared to the freshly isolated vessels. In addition, no difference was found in response to the other constrictive substances apart from slightly augmented response to PHE (compare fig. 1a with $2 \mathrm{~b}, 14.4 \pm 0.2$ vs. $16.9 \pm 0.7 \%$ of high $\mathrm{K}^{+}$response, $\mathrm{p}<0.05$ ) in veins and a tendency towards an increase in response to S6c (compare fig. 1a with 2a, $61 \pm$ 15 vs. $108 \pm 17 \%$ of high $\mathrm{K}^{+}$response, $\mathrm{p}=0.06$ ) in arteries after incubation. In veins, incubation moderately attenuated the endothelium-dependent relaxation to $\mathrm{ACH}$ (compare fig. $1 \mathrm{~b}$ with $3 \mathrm{~b}, 79.3 \pm 7.9$ vs. $46.8 \pm 7.4 \%$ relaxation of maximal U46619-induced contraction), while the artery was not significantly affected. Moreover, the effect of ISO, studied in arteries and veins and SNP, studied in vein only, was not altered by incubation (fig. 3a, b).

\section{Effects of Incubation with Endotoxin on Vascular}

\section{Reactivity}

Incubation with endotoxin $10 \mu \mathrm{g} \cdot \mathrm{ml}^{-1}$ during $24 \mathrm{~h}$ induced a significant decrease in the high $\mathrm{K}^{+}$induced active tension of veins but not in arteries (table 1). Moreover, endotoxin also induced markedly lowered responses in both arteries and veins in response to PHE (fig. 2a, b). In veins selectively, the contraction induced by S6c and ET-1 was relatively augmented by endotoxin (fig. $2 b, d, f$ ), while the response to the other contractile agonists, except PHE, was not altered by endotoxin in arteries nor veins (fig. 2a, d).

The effects of the vasodilating compounds $\mathrm{ACH}$ and ISO were not significantly changed by endotoxin, although there was a weak tendency $(\mathrm{p}=0.16)$ suggesting a modest impairment of the endothelium-dependent vasodilation of $\mathrm{ACH}$ in veins only. The effect of the NO-donor SNP in veins was unchanged by endotoxin incubation (fig. 3a, b).

\section{Immunohistochemistry and Western Blotting}

Immunohistochemistry was performed to localize the $\mathrm{ET}_{\mathrm{A}}$ and $\mathrm{ET}_{\mathrm{B}}$ receptors within the vascular tissue and to study the gross morphology of freshly isolated, incubated and endotoxin-incubated preparations. The vascular smooth muscle and the endothelial cell layer showed no signs of disruption or swelling after incubation or endotoxin exposure (data not shown). Staining against $\alpha$-actin 


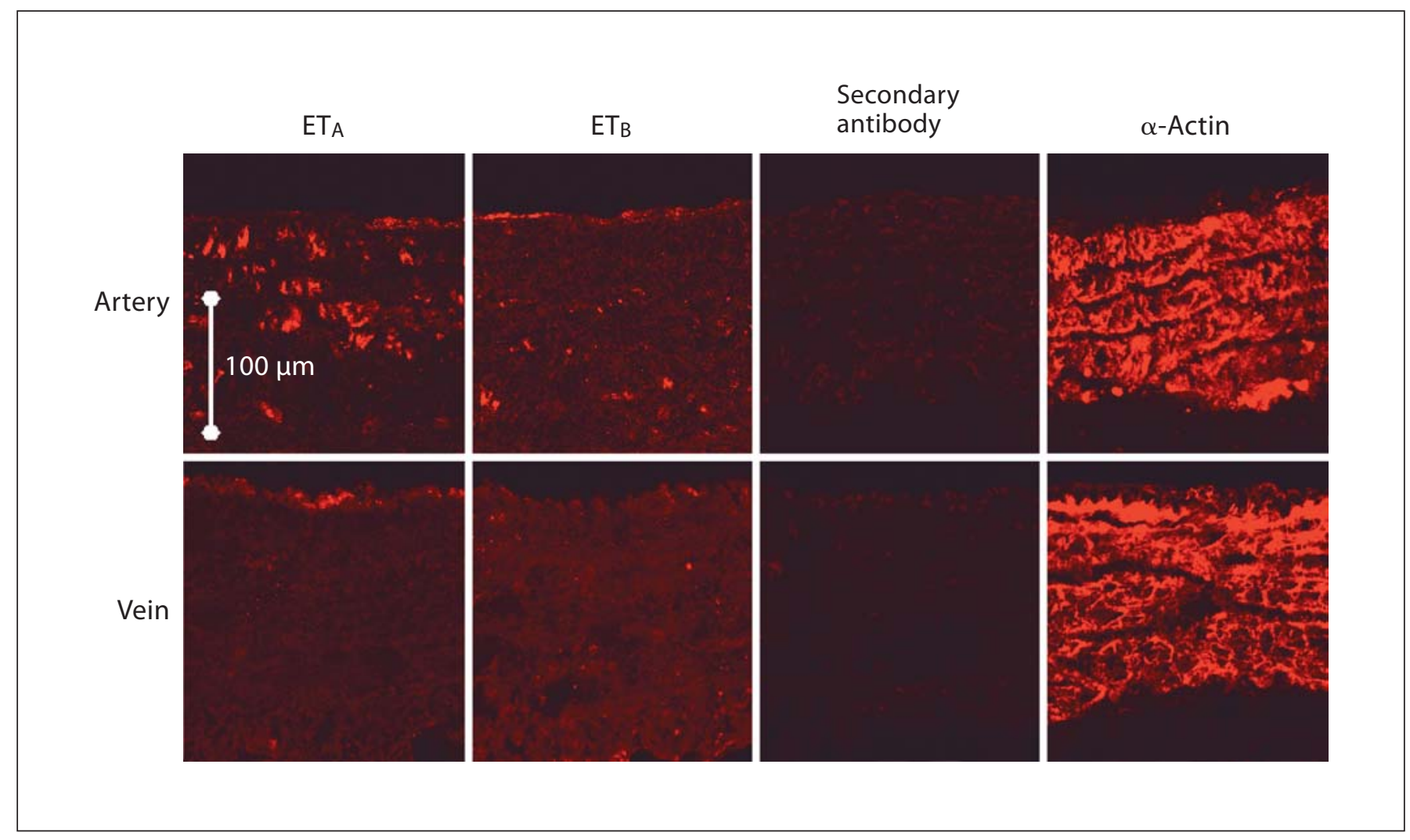

Fig. 4. Confocal microscopy images displaying representative examples of immunohistochemistry staining for the $\mathrm{ET}_{\mathrm{A}}$ receptor, $\mathrm{ET}_{\mathrm{B}}$ receptor, secondary antibody only and smooth muscle $\alpha$-actin. Freshly isolated preparations of pulmonary artery (top) and pulmonary vein (bottom). The vessel lumen is given on top of the images.

showed equally intense staining in the smooth muscle cell layer of all preparations (fig. 4). In fresh as well as in incubated vessels, the $\mathrm{ET}_{\mathrm{A}}$ receptors were preferentially located in the vascular smooth muscle cells, whereas the $\mathrm{ET}_{\mathrm{B}}$ receptors were located in the endothelial as well as the vascular smooth muscle cell layer (fig. 4, 5a, b). No difference in ET receptor staining intensity or distribution could be detected between freshly isolated arteries and veins or between incubated and endotoxin-exposed vessels (fig. 4, 5a, b).

The expression of $\mathrm{ET}_{\mathrm{A}}$ and $\mathrm{ET}_{\mathrm{B}}$ receptor protein was investigated using Western blot and compared to $\alpha$-actin protein levels. In arteries, the levels of both $\mathrm{ET}_{\mathrm{A}}$ and $\mathrm{ET}_{\mathrm{B}}$ receptor protein expressions was higher compared to the levels in veins, using the same amount of protein loaded on the gel (data not shown). This difference was not affected by incubation per se or by endotoxin (table 1). Moreover, no difference in expression of ET receptor protein (table 1) or $\alpha$-actin (data not shown) was detected between freshly isolated, incubated or endotoxin-exposed vessels.

\section{Discussion}

In the present study, we developed an organ culture system for porcine pulmonary vessels and investigated the effects of $24 \mathrm{~h}$ exposure to endotoxin. We examined effects on responses to contractile and relaxant substances that are considered important either for the pathogenesis or for the treatment of sepsis and ALI in man. The major findings are that endotoxin induces changes that differentially affect the reactivity of pulmonary arteries and veins. The sum of these endotoxin-induced disturbances in vascular reactivity might favor an increase in the pulmonary venous resistance compared to the arterial resistance, changes that in vivo may augment the filtration pressure in the pulmonary capillaries.

In freshly isolated vessels, the $\alpha-1$ receptor agonist PHE induced a more than 5-fold stronger contraction in pulmonary arteries than veins. This finding is consistent with previous studies $[22,23]$ demonstrating a negligible constriction in pulmonary veins compared to arteries in- 


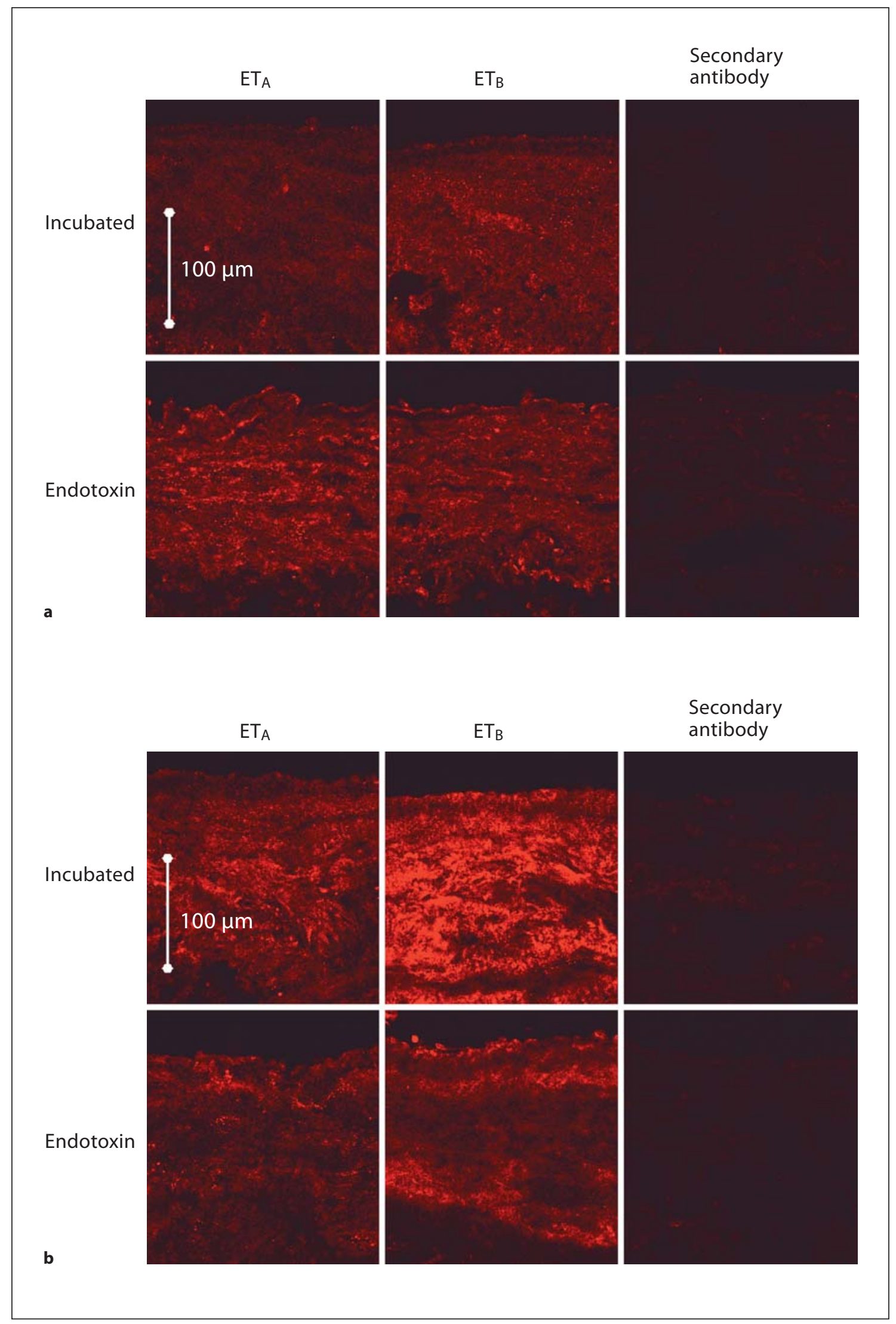


duced by noradrenaline. Bäck et al. [22] suggested that this difference was the result of formation of endogenous NO in the vein, as inhibition of NO synthase markedly enhanced noradrenaline-induced contractions. In contrast to the prominent and preferentially arterial constriction induced by PHE, the $\alpha-2$ receptor agonist UK14.304 elicited rather small and equal contractions in both preparations. Postjunctional $\alpha-2$ adrenergic receptors mediating vasoconstriction have previously been described in the pulmonary circulation of various species [24-26] and the canine pulmonary vein has been reported to be more sensitive than the artery to $\alpha-2$ receptor agonists [25]. This discrepancy to our findings could possibly be attributed to differences in used experimental model and species. Moreover, the clinical significance of the small contractions is unclear and $\alpha-2$ receptor agonists have been used uneventfully in patients with pulmonary hypertension [27].

Thromboxane $\mathrm{A}_{2}$ is regarded as a potent and important mediator of pulmonary vascular constriction [28]. Interestingly, in vitro and ex vivo studies have indicated that thromboxane $\mathrm{A}_{2}$ not only induces a venous constriction $[29,30]$, but also promotes the formation of pulmonary edema [31]. Moreover, Walch et al. [29] studied human pulmonary veins reporting that U46619 induces a constriction $50 \%$ higher than that of noradrenaline. Results from arteries were not reported. Similar findings were seen in the present study where U46619 induced a contraction in pulmonary veins that was almost 5 -fold stronger than that of PHE, a notable difference, compared with the relative response to these agonists in arteries. However, the contractions were equally powerful in arterial and venous preparations when related to the high $\mathrm{K}^{+}$response suggesting a limited difference in arterial and venous responses to thromboxane. In addition, the reaction to $\mathrm{PGF}_{2 \alpha}$, another highly vasoactive metabolite of arachidonic acid that is produced in inflammatory states like endotoxemia [32], was equal in arteries and veins.

The differential effects of the ET system on the pulmonary vascular tone have previously been investigated in

Fig. 5. Confocal images displaying representative examples of immunohistochemistry staining for the $\mathrm{ET}_{\mathrm{A}}$ receptor, $\mathrm{ET}_{\mathrm{B}}$ receptor and secondary antibody. Isolated preparations of pulmonary artery (a) and pulmonary vein (b), incubated for $24 \mathrm{~h}$ with (bottom) or without (top) endotoxin $10 \mu \mathrm{g} \cdot \mathrm{ml}^{-1}$. The vessel lumen is given on top of the images.

Effects of Endotoxin on Pulmonary Arteries and Veins various species, partly with conflicting results. Brink et al. [33], using human pulmonary vessel preparations, found the pulmonary vein to be more sensitive than the artery to ET-1, and similar results have been reported by others in different species $[34,35]$. In contrast to those results, Kemp et al. [30] and Zellers et al. [36] found no arterial to venous difference in sensitivity to ET-1 using pulmonary vessels of ovine and porcine origin. The latter findings are in line with the present study, where freshly isolated vessels, in contrast to endotoxin exposed, showed no arterial to venous difference in response to ET-1.

The finding that the selective $\mathrm{ET}_{\mathrm{B}}$ receptor agonist $\mathrm{S} 6 \mathrm{c}$ causes a predominant venous constriction is consistent with previous studies using both in vitro $[6,36,37]$ and in vivo [6] preparations, suggesting that the $\mathrm{ET}_{\mathrm{B}}$ receptor expression/function is a major factor determining the differential responses to ET in arteries and veins.

The $\beta$-adrenoceptor agonist ISO was more potent in relaxing veins than arteries, and its actions were not affected by endotoxin. Even though clinical use of $\beta$-agonists in ALI primarily is aimed at treating bronchoconstriction, there is growing evidence that $\beta$-agonists can reduce pulmonary edema $[38,39]$. These effects of $\beta$-agonists have mainly been attributed to enhanced clearance of alveolar fluid by stimulation of sodium and water reabsorption through the alveolar epithelium. The findings of the present study suggest that a venous dilatation by $\beta$-agonists can provide an additional effect leading to a reduction of the pulmonary capillary and filtration pressure. This potentially beneficial effect needs further investigations using in vivo experiments.

The vessel incubation procedure induced only minor changes in the contractile patterns of the porcine pulmonary vessels. This finding is partly in contrast to previous reports on human, rodent and porcine nonpulmonary systemic vessels which have indicated that organ culture may induce an upregulation of contractile $\mathrm{ET}_{\mathrm{B}}$ receptors located on vascular smooth muscle cells $[40,41]$ or a downregulation of dilatory endothelial $\mathrm{ET}_{\mathrm{B}}$ receptors [42]. In the present study, incubation did not induce any statistically significant changes in response to ET receptor stimulation even though there was a trend towards increased S6c sensitivity in the pulmonary arteries after incubation. However, the analysis of protein expression with immunohistochemistry and Western blot did not reveal any apparent changes of $\mathrm{ET}_{\mathrm{B}}$ receptor distribution or expression after incubation. It is possible that pulmonary vessels are less affected by the short-term culture conditions as compared with nonpulmonary vessels used in the above-mentioned studies. 
Endotoxin induced a substantial vascular hyporeactivity in response to PHE, which was evident both in arteries and veins. These findings from the pulmonary vasculature are consistent with reports demonstrating endotoxin-induced hyporeactivity to $\alpha-1$ adrenergic agonists in other vessel beds and species $[5,15,43]$, including humans [44]. These reactions have been reported both after in vitro and in vivo application of endotoxin and have been suggested to involve the actions of $\mathrm{NO}$ and an increased action of soluble guanylate cyclase. That NO is highly involved especially in early sepsis-induced vascular hyporeactivity has been suggested by several reports [45]. Increased levels of $\mathrm{NO}$ breakdown products in sepsis patients have been reported and inhibition of the actions of NO has successfully been used to increase blood pressure in sepsis patients [46]. The results of the present study indicate that vessels in the pulmonary circulation are also prone to develop hyporeactivity to $\alpha$-adrenergic stimulation after exposure to endotoxin. It is, to our knowledge, unknown if these disturbances in adrenergic signaling are present in the pulmonary circulation during septic shock and whether these changes are important for development of sepsis-induced pulmonary edema remains to be investigated. In contrast to the diminished reactions to the $\alpha-1$ agonist, the contractions induced by the $\alpha-2$ adrenergic agonist UK14.304 and the arachidonic acid metabolites $\mathrm{U} 46619$ and $\mathrm{PGF}_{2 \alpha}$, were left unaffected in arteries and veins after endotoxin exposure. This indicates that endotoxin interacts with specific receptors or cellular signaling pathways in the pulmonary vessels.

Endotoxin reduced the responses to membrane high $\mathrm{K}^{+}$depolarization in pulmonary veins without affecting the arteries significantly. This might relate to a general downregulation of contractile components or to a change in $\mathrm{Ca}^{2+}$ influx. The link between endotoxin exposure and these changes is not clarified. However, endotoxin did not attenuate the responses to ET-1 and S6c. Instead, the responses to ET receptor agonism in pulmonary veins were increased in relation to other contractile agonists. Interestingly, the ET receptor response in arteries was not increased. If these differential effects of endotoxin on the arterial and venous vessels shown in our in vitro study can be extrapolated to a change in the ET receptor-mediated reactivity in vivo remains to be clarified. The importance of pulmonary venous tone has gained increased attention during the last decades, since it may have an impact on pulmonary fluid filtration and ventilation/ perfusion matching [28]. The results of the present study suggest that ET receptor-mediated venoconstriction could be enhanced in endotoxemia and have a significant impact on postcapillary resistances especially in conditions such as endotoxaemia or sepsis when circulating ET-1 levels are markedly elevated [8]. This is consistent with previous reports from our laboratory indicating that endotoxin in vivo predominantly induces an increase in the pulmonary venous resistance and enhances the formation of pulmonary edema $[3,6,12]$. Interestingly, these changes could be counteracted by ET receptor antagonists [3]. These changes in reactivity to ET receptor stimulation induced by endotoxin in pulmonary veins can involve alterations in expression or distribution of ET receptors, for example increased expression of contractile $\mathrm{ET}_{\mathrm{A}}$ or $\mathrm{ET}_{\mathrm{B}}$ receptors on the vascular smooth muscle cells or by a downregulation of relaxing $\mathrm{ET}_{\mathrm{B}}$ receptors on the endothelium. We could, however, with immunohistochemistry, detect $\mathrm{ET}_{\mathrm{B}}$ receptors in the endothelium and did not observe an upregulation of the ET receptors in the smooth muscle layer after endotoxin treatment. Furthermore, the Western blot analyses showed that the relative amounts of ET receptors was not changed by endotoxin incubation. It is possible that the sensitivity of these analyses is insufficient to resolve small but important changes of ET receptor expression or distribution, but other explanations are also possible. Since endotoxin is known to interact with several cellular processes, the observed changes in ET receptor responses after endotoxin incubation might involve changes in intracellular signaling pathways affecting the coupling between ET receptors and contractile activation/deactivation in combination with, or instead of, effects on the ET receptor expression per se.

The incubation attenuated the endothelium-dependent vasodilatation by $\mathrm{ACH}$ somewhat in veins, making analysis of endotoxin effects on endothelium-induced relaxation difficult in this model system. However, the $\mathrm{ACH}$ responses tended to be further diminished by endotoxin in the veins while the endothelium-independent responses to ISO and SNP remained unaffected, suggesting that the endothelial function was disturbed by incubation and endotoxin in the vein. In this context it should be noted that ET-1 and S6c also induce relaxation of vessels via endothelial $\mathrm{ET}_{\mathrm{B}}$ receptors and release of $\mathrm{NO}$ and prostacyclin. It is therefore possible that the augmented responses to ET-1 and S6c in veins after endotoxin exposure may also include a component of endothelial impairment affecting the relaxing effects of endothelial $\mathrm{ET}_{\mathrm{B}}$ receptor unmasking the constrictive effects of the $\mathrm{ET}_{\mathrm{A}}$ and $\mathrm{ET}_{\mathrm{B}}$ receptors on the smooth muscle cells. In the present study we could not detect any morphologic changes after 
incubation or endotoxin exposure, suggesting that the endothelial impairment might be related to intracellular changes and not to endothelial disruption or shedding.

The concentration of endotoxin $\left(10 \mu \mathrm{g} \cdot \mathrm{ml}^{-1}\right)$ was chosen after a pilot study and is similar to those used in other studies [15, 47]. Interestingly, O'Brien et al. [15] reported equal hyporeactivity of rat mesenteric artery induced by endotoxin (Salmonella typhosa) $1-100 \mu \mathrm{g} \cdot \mathrm{ml}^{-1}$ when assessed with PHE. Moreover, in their report the duration of incubation was more important than the concentration of endotoxin. Little is known about the time course of endotoxemia during sepsis and the level varies considerable between patients. However, the concentrations used in in vitro or in vivo studies [48] widely exceed those reported on plasma levels of septic patients in the intensive care setting (range $0.06-0.5 \mathrm{ng} \cdot \mathrm{ml}^{-1}$ ) [49-51]. In vivo, an endotoxin insult will result in a generalized inflammatory response involving the actions of numerous cells and the release of several mediators, whereas in vitro the response is limited to the exposed experimental cell population, making comparisons between these setting complicated. Furthermore, the present study investigates pharmacological pathways which may affect the pulmonary capillary hydrostatic pressure in vivo. Even though this pressure is highly important for the formation of pulmonary edema, other forces of the Starling equilibrium (such as capillary permeability and oncotic pressures) as well as clearance of alveolar fluid are affected during sepsis and might also be of major importance for the formation of extravascular lung water. Moreover, although studies using isolated tissues exposed to separate pharmacologic stimuli may facilitate investigations of basic mechanisms, additional studies in vivo are needed before in vitro results can be translated to whole animal settings, not to mention to the clinical situation.

In summary, this study shows that endotoxin induces differentiated effects on isolated porcine pulmonary arteries and veins. Endotoxin leads to lowered responses to $\alpha-1$ adrenergic stimulation with a predominant effect on the arteries. Concurrently, endotoxin induces a relative augmentation of the contractile response to both ET-1 and S6c in the pulmonary veins, without altering any apparent expressions or distributions of ET-receptors. Taken together, these endotoxin-induced changes in the arterial and venous contractile responses to the adrenergic and ET pathways can, especially during increased sympathetic activity and high ET levels, influence the balance in tone between pulmonary arteries and veins. If these results are extrapolated to the clinical situation, this will increase the pulmonary capillary filtration pressure and have an effect on the formation of pulmonary edema, especially during conditions (for example sepsis) when other edema-promoting factors, such as increased capillary permeability or decreased oncotic pressure, are present.

\section{Acknowledgments}

This study was supported by the Swedish Research Council, the Swedish Heart-Lung Foundation, Funds from Karolinska Institutet and Swedish Society of Medicine. Financial support was also provided through the regional agreement on medical and clinical research (ALF) between Stockholm County Council and Karolinska Institutet.

\section{References}

1 Baumgarten G, Knuefermann P, Wrigge H, Putensen C, Stapel H, Fink K, Meyer R, Hoeft A, Grohe C: Role of Toll-like receptor 4 for the pathogenesis of acute lung injury in Gram-negative sepsis. Eur J Anaesthesiol 2006;23:1041-1048.

- Wang HM, Bodenstein M, Markstaller K: Overview of the pathology of three widely used animal models of acute lung injury. Eur Surg Res 2008;40:305-316.

-3 Rossi P, Wanecek M, Konrad D, Oldner A: Tezosentan counteracts endotoxin-induced pulmonary edema and improves gas exchange. Shock 2004;21:543-548.
4 Kabir K, Gelinas JP, Chen M, Chen D, Zhang D, Luo X, Yang JH, Carter D, Rabinovici R: Characterization of a murine model of endotoxin-induced acute lung injury. Shock 2002; 17:300-303.

5 Matsuda N, Hattori Y: Vascular biology in sepsis: pathophysiological and therapeutic significance of vascular dysfunction. J Smooth Muscle Res 2007;43:117-137.

-6 Rossi P, Persson B, Boels PJ, Arner A, Weitzberg E, Oldner A: Endotoxemic pulmonary hypertension is largely mediated by endothelin-induced venous constriction. Intensive Care Med 2008;34:873-880.

7 Battistini B, Dussault P: Biosynthesis, distribution and metabolism of endothelins in the pulmonary system. Pulm Pharmacol Ther 1998;11:79-88.
8 Weitzberg E, Lundberg JM, Rudehill A: Elevated plasma levels of endothelin in patients with sepsis syndrome. Circ Shock 1991;33: 222-227.

-9 Mitaka C, Hirata Y, Nagura T, Tsunoda Y, Amaha K: Circulating endothelin-1 concentrations in acute respiratory failure. Chest 1993; 104:476-480.

10 Langleben D, DeMarchie M, Laporta D, Spanier AH, Schlesinger RD, Stewart DJ: Endothelin-1 in acute lung injury and the adult respiratory distress syndrome. Am Rev Respir Dis 1993;148:1646-1650.

11 Druml W, Steltzer H, Waldhausl W, Lenz K, Hammerle A, Vierhapper H, Gasic S, Wagner OF: Endothelin-1 in adult respiratory distress syndrome. Am Rev Respir Dis 1993; 148:1169-1173. 
-12 Persson BP, Rossi P, Weitzberg E, Oldner A: Inhaled tezosentan reduces pulmonary hypertension in endotoxin-induced lung injury. Shock 2009;32:427-434.

13 Kuklin VN, Kirov MY, Evgenov OV, Sovershaev MA, Sjoberg J, Kirova SS, Bjertnaes LJ: Novel endothelin receptor antagonist attenuates endotoxin-induced lung injury in sheep. Crit Care Med 2004;32:766-773.

- 14 de Nucci G, Thomas R, D’Orleans-Juste P, Antunes E, Walder C, Warner TD, Vane JR: Pressor effects of circulating endothelin are limited by its removal in the pulmonary circulation and by the release of prostacyclin and endothelium-derived relaxing factor. Proc Natl Acad Sci USA 1988;85:9797-9800.

-15 O’Brien AJ, Wilson AJ, Sibbald R, Singer M, Clapp LH: Temporal variation in endotoxininduced vascular hyporeactivity in a rat mesenteric artery organ culture model. Br J Pharmacol 2001;133:351-360.

-16 Foudi N, Kotelevets L, Louedec L, Leseche G, Henin D, Chastre E, Norel X: Vasorelaxation induced by prostaglandin e2 in human pulmonary vein: Role of the ep4 receptor subtype. Br J Pharmacol 2008;154:1631-1639.

- 17 Fernandes D, da Silva-Santos JE, Duma D, Villela CG, Barja-Fidalgo C, Assreuy J: Nitric oxide-dependent reduction in soluble guanylate cyclase functionality accounts for early lipopolysaccharide-induced changes in vascular reactivity. Mol Pharmacol 2006;69: 983-990.

18 Parker JL, Adams HR: Selective inhibition of endothelium-dependent vasodilator capacity by Escherichia coli endotoxemia. Circ Res 1993;72:539-551.

-19 Piepot HA, Groeneveld AB, van Lambalgen AA, Sipkema P: Endotoxin impairs endothelium-dependent vasodilation more in the coronary and renal arteries than in other arteries of the rat. J Surg Res 2003;110:413-418.

20 Boels PJ, Deutsch J, Gao B, Haworth SG: Maturation of the response to bradykinin in resistance and conduit pulmonary arteries. Cardiovasc Res 1999;44:416-428.

-21 Boels PJ, Deutsch J, Gao B, Haworth SG: Perinatal development influences mechanisms of bradykinin-induced relaxations in pulmonary resistance and conduit arteries differently. Cardiovasc Res 2001;51:140-150.

-22 Bäck M, Walch L, Norel X, Gascard JP, Mazmanian G, Brink C: Modulation of vascular tone and reactivity by nitric oxide in porcine pulmonary arteries and veins. Acta Physiol Scand 2002;174:9-15.

-23 Joiner PD, Kadowitz PJ, Hughes JP, Hyman AL: Ne and ach responses of intrapulmonary vessels from dog, swine, sheep, and man. Am J Physiol 1975;228:1821-1827.

-24 Gornemann T, von Wenckstern H, Kleuser B, Villalon CM, Centurion D, Jahnichen S, Pertz HH: Characterization of the postjunctional $\alpha 2 \mathrm{c}$-adrenoceptor mediating vasoconstriction to uk14304 in porcine pulmonaryveins. Br J Pharmacol 2007;151:186-194.
25 Shebuski RJ, Ohlstein EH, Smith JM Jr, Ruffolo RR Jr: Enhanced pulmonary $\alpha-2$ adrenoceptor responsiveness under conditions of elevated pulmonary vascular tone. J Pharmacol Exp Ther 1987;242:158-165.

26 Hyman AL, Kadowitz PJ: Evidence for existence of postjunctional $\alpha 1$ - and $\alpha 2$-adrenoceptors in cat pulmonary vascular bed. Am J Physiol 1985;249:H891-H898.

27 But AK, Ozgul U, Erdil F, Gulhas N, Toprak HI, Durmus M, Ersoy MO: The effects of pre-operative dexmedetomidine infusion on hemodynamics in patients with pulmonary hypertension undergoing mitral valve replacement surgery. Acta Anaesthesiol Scand 2006;50:1207-1212.

28 Gao Y, Raj JU: Role of veins in regulation of pulmonary circulation. Am J Physiol Lung Cell Mol Physiol 2005;288:L213-L226.

$>29$ Walch L, de Montpreville V, Brink C, Norel $\mathrm{X}$ : Prostanoid EP(1)- and TP-receptors involved in the contraction of human pulmonary veins. Br J Pharmacol 2001;134:16711678 .

30 Kemp BK, Smolich JJ, Cocks TM: Evidence for specific regional patterns of responses to different vasoconstrictors and vasodilators in sheep isolated pulmonary arteries and veins. Br J Pharmacol 1997;121:441-450.

-31 Shibamoto T, Wang HG, Yamaguchi Y, Hayashi T, Saeki Y, Tanaka S, Koyama S: Effects of thromboxane a 2 analogue on vascular resistance distribution and permeability in isolated blood-perfused dog lungs. Lung 1995;173:209-221.

>32 Basu S: Novel cyclooxygenase-catalyzed bioactive prostaglandin $\mathrm{f} 2 \alpha$ from physiology to new principles in inflammation. Med Res Rev 2007;27:435-468.

33 Brink C, Gillard V, Roubert P, Mencia-Huerta JM, Chabrier PE, Braquet P, Verley J: Effects and specific binding sites of endothelin in human lung preparations. Pulm Pharmacol 1991;4:54-59.

-34 Toga H, Ibe BO, Raj JU: In vitro responses of ovine intrapulmonary arteries and veins to endothelin-1. Am J Physiol 1992;263:L15L21.

-35 Aharinejad S, Schraufnagel DE, Miksovsky A, Larson EK, Marks SC Jr: Endothelin-1 focally constricts pulmonary veins in rats. J Thorac Cardiovasc Surg 1995;110:148-156.

36 Zellers TM, McCormick J, Wu Y: Interaction among ET-1, endothelium-derived nitric oxide, and prostacyclin in pulmonary arteries and veins. Am J Physiol 1994;267:H139H147.

-37 Sudjarwo SA, Hori M, Takai M, Urade Y, Okada T, Karaki H: A novel subtype of endothelin $\mathrm{B}$ receptor mediating contraction in swine pulmonary vein. Life Sci 1993;53:431437.

38 Perkins GD, McAuley DF, Thickett DR, Gao F: The $\beta$-agonist lung injury trial (BALTI): a randomized placebo-controlled clinical trial. Am J Respir Crit Care Med 2006;173:281287.
39 Sartori C, Allemann Y, Duplain H, Lepori M, Egli M, Lipp E, Hutter D, Turini P, Hugli O, Cook S, Nicod P, Scherrer U: Salmeterol for the prevention of high-altitude pulmonary edema. N Engl J Med 2002;346:1631-1636.

40 Johnsson E, Maddahi A, Wackenfors A, Edvinsson L: Enhanced expression of contractile endothelin $\mathrm{ET}(\mathrm{B})$ receptors in rat coronary artery after organ culture. Eur J Pharmacol 2008;582:94-101.

41 Adner M, Uddman E, Cardell LO, Edvinsson L: Regional variation in appearance of vascular contractile endothelin-B receptors following organ culture. Cardiovasc Res 1998; 37:254-262.

-42 Nilsson D, Wackenfors A, Gustafsson L, Ugander M, Paulsson P, Ingemansson R, Edvinsson L, Malmsjo M: Endothelin receptormediated vasodilatation: effects of organ culture. Eur J Pharmacol 2008;579:233-240.

43 Piepot HA, Groeneveld AB, van Lambalgen AA, Sipkema P: The role of inducible nitric oxide synthase in lipopolysaccharide-mediated hyporeactivity to vasoconstrictors differs among isolated rat arteries. Clin Sci (Lond) 2002;102:297-305.

$\checkmark 44$ Foudi N, Louedec L, Cachina T, Brink C, Norel X: Selective cyclooxygenase-2 inhibition directly increases human vascular reactivity to norepinephrine during acute inflammation. Cardiovasc Res 2009;81:269277.

45 Fernandes D, Assreuy J: Nitric oxide and vascular reactivity in sepsis. Shock 2008; 30(suppl 1):10-13.

46 Kwok ES, Howes D: Use of methylene blue in sepsis: A systematic review. J Intensive Care Med 2006;21:359-363.

47 El-Awady MS, Smirnov SV, Watson ML: Desensitization of the soluble guanylyl cyclase/ cGMP pathway by lipopolysaccharide in rat isolated pulmonary artery but not aorta. Br J Pharmacol 2008;155:1164-1173.

48 Carlsson M, Lipcsey M, Larsson A, Tano E, Rubertsson S, Eriksson M, Sjolin J: Inflammatory and circulatory effects of the reduction of endotoxin concentration in established porcine endotoxemic shock - a model of endotoxin elimination. Crit Care Med 2009;37:e1031-e1034.

49 Danner RL, Elin RJ, Hosseini JM, Wesley RA, Reilly JM, Parillo JE: Endotoxemia in human septic shock. Chest 1991;99:169-175.

50 Guidet B, Barakett V, Vassal T, Petit JC, Offenstadt G: Endotoxemia and bacteremia in patients with sepsis syndrome in the intensive care unit. Chest 1994;106:1194-1201.

51 Venet C, Zeni F, Viallon A, Ross A, Pain P, Gery P, Page D, Vermesch R, Bertrand M, Rancon F, Bertrand JC: Endotoxaemia in patients with severe sepsis or septic shock. Intensive Care Med 2000;26:538-544. 